\title{
CHALLENGES OF ORGANIC AGRICULTURE FOR THE PRODUCTION OF COMPOSTS AND VERMICOMPOST FOR THE PRODUCTION OF MEDICINAL PLANTS - A SOCIOECONOMIC DEMAND
}

\author{
DESAFIOS DA AGRICULTURA ORGÂNICA NA PRODUÇÃO DE COMPOSTO E \\ VERMICOMPOSTO NA PRODUÇÃO DE PLANTAS MEDICINAIS: UMA DEMANDA \\ SOCIOECONOAMICA
}

\section{Maysa Mathias Alves PEREIRA ${ }^{\mathbf{1}}$; Ludmila Caproni MORAIS ${ }^{\mathbf{1}}$; Adalvan Daniel MARTINS ${ }^{\mathbf{1}}$; José Magno Queiroz LUZ ${ }^{2}$; Moacir PASQUAL ${ }^{1}$; Roberta Camargos OLIVEIRA ${ }^{2}$; Joyce DÓRIA ${ }^{1}$}

1. Department of Agriculture, Federal University of Lavras, Lavras, MG, Brasil. agro.maysa@gmail.com; 2. Institute of Agricultural Sciences, Federal University of Uberlândia, Uberlândia, MG, Brasil.

\begin{abstract}
Although the demand for organic fertilizers in agriculture is growing, it remains incipient in some production sectors, such as medicinal plant production, which does not possess specific technology for its development. Solid residues are highly contaminant to water sources, soil, populations and biodiversity but can potentially be used to produce organic composts and vermicompost, such production not only enables nutrient recycling but also acts on soil conditioning, increasing soil organic matter and improving its physical, chemical and biological characteristics, as well as strengthening organic production with an emphasis on medicinal plant production. In this context, recommendations for and applications of organic fertilizers available in the market were reviewed; in addition, the imminent socioeconomic demand for organic compost and vermicompost production was contextualized based on residues from coffee and sugarcane production and cattle farming for application to the medicinal plant production chain. It is concluded that although these sectors produce a considerable amount of residues, they are not being reused in formulation of organic composts and vermicompost, and commercial organic fertilizers recommended for medicinal plant production were not found. Thus, the formulation of vermicomposting and composting from the reuse of agricultural residues, are potential social, economic technologies and tools to be valued and disseminated to traditional and family farmers.
\end{abstract}

KEYWORDS: Agroecology. Horticulture. Secondary metabolism. Solid residues. Sustainability.

\section{INTRODUCTION}

Medicinal plants play an important role in health maintenance and comprise the most accessible treatment for $80 \%$ of the population (SOUZA-MOREIRA, 2010). The medicinal plant sector is a promising market, with revenue of approximately U\$ 160 million/year in Brazil, and medicinal plants are its raw material (RODRIGUES, 2016).

The cultivation of medicinal plants demands care, since they are used for therapeutic purposes, and organic practices are therefore of interest. Accordingly, the use of organic composts and vermicompost in agriculture is of great relevance, since it is associated with care for the environment (SANTOS et al.,2014;WU et al., 2014; COTTA et al., 2015) being beneficial for biodiversity, environment, fauna and consumers, which have a high demand for products that are free from chemicals and/or genetic modification (WILLER,
2010; LOPEZ-GONZALEZ et al., 2013; JIANG et al., 2016).

Agricultural and animal farming residues, when disposed of inadequately and in a disorderly manner, have environmental impacts because of the generation of large quantities of contaminants, such as feces, toxic metals, inorganic salts, pathogens, lixiviation and toxic gas emission, especially in containment systems (ERTHA 2010; LIMA et al., 2013; NOGUEIRA, 2015), nutrient immobilization by microorganisms, and contamination of water reserves (SILVA, 2008). However, these residues can potentially be used in the formulation of vermicompost and organic composts that can be applied to medicinal plant production (WU et al., 2014; MORAES, 2015; SOARES et al., 2017).

Recommendations for organic composts and vermicompost for medicinal plant cultivation that may result in both biomass gain and increased concentrations of bioactive compounds with pharmacological and biological interest remain 
incipient. Therefore, the aim of this review was to contextualize the importance of reusing agricultural and animal farming residues to produce organic composts and vermicompost aimed at the production of medicinal plants and active compounds of pharmacological and biological interest.

\section{DEVELOPMENT}

The bibliographic research was carried out by compiling publications on agricultural bases indexed on free access digital platforms that work with the commercialization of organic fertilizers. The companies evaluated in this research were (1) Terra Fértil; (2) Plantei; (3) NutriSafra; (4) MfRural; (5) Neudfor; (6) Agrobio; (7) Folhito Mix; (8) Fish fértil; (9) Microbio. The total of 33 organic fertilizers made available by these companies were listed and the analysis and systematization of the commercial name, composition and agricultural recommendation of organic fertilizers for the crops of interest were made.

\section{Factors determining the stagnation of medicinal plant production}

The establishment of agricultural production chains is not an isolated factor within the economic development of countries; there are socioeconomic and historical processes intrinsic to the production of food, goods and services (SOUSA; GOIÁIS, 2015). In this context, changes in agriculture began with the Green Revolution and culminated in the economic globalization that began in the 1990s; this globalization was organized around large companies, agricultural industries and multinationals that control the world market LAZZARI; SOUZA, 2017; MATOS; PESSOA, 2011). Ever since the colonial period, an essentially organic based-agriculture has been replaced by techniques that depend on chemical inputs, whereas the Brazilian agricultural policy prioritizes incentives to commodity export (FLORES; GREGORI; ARAÚJO, 2013; PEREIRA; SOUSA, 2016; GURGEL; GIRALDO, 2017) with agribusiness justifying production chains that have the goal of gathering agrochemical, industrial and commercial activities and land monopolies and directing them toward the external market (SAUER; LEITE, 2012; MENDONÇA, 2015).

To establish agriculture and animal farming, it has been necessary to standardize cultivation and to industrialize and optimize production chains, which are essential factors in the expansion of agribusiness at an international level, consolidating the standard food production model in Brazil (SAMPAIO; NETO, 2018).

In parallel with the green revolution, the industrial revolution promoted the industrialization of the countryside, which had strong environmental impacts caused by the intensive use of fossil fuels (PEREIRA; SOUSA, 2016; SAMPAIO; NETO, 2018). In this context, the pharmaceutical industries developed side by side, comprising the hegemonic production model of "disease and cure" and contributing to the irrational use of agrotoxics and drugs as a way of maintaining profit and hegemony (MONTEIRO; LACERDA, 2016; MENDONÇA et al., 2015; BARROS, 2018).

Therefore, although populations have historically used medicinal plants, after the industrial revolution, natural products were replaced by synthetic drugs on a massive scale. The New Chemical Entities of pharmaceutical products recorded that at least $27 \%$ of synthetic drugs originate from plant biodiversity and are formulated from natural products via chemical synthesis (ALVES; PONTES, 2017). Therefore, there is a deficit in the development of services, technologies and research related to medicinal plant production in Brazil (TORRES, 2015).

The stagnation observed in medicinal plant production is caused by the fact that food, natural products and drug production are not foreign to societal factors but instead depend on political and economic interests (RONDÓ; LOPES, 2016). In this scenario, medicinal plant production was not historically recognized as an agricultural production chain or as having political and economic interest; it only reemerged as potent and innovative in the 2000s (PIMENTEL, 2015). Accordingly, there is an imminent demand for technologies and research in medicinal plant production (HEINZMANN; BARROS, 2007; RIBEIRO et al., 2014; ASSIS; MORELLI-AMARAL; PIMENTA, 2015).

\section{The brazilian scenario of medicinal plant and herbal drug production: expanding demand}

The use of medicinal plants in popular medicine in Brazil, especially by traditional peoples (Quilombolas, Native Peoples, Riparian Communities), is historically expressive and has been exploited by Brazilian researchers and the pharmaceutical industry (CALIXTO; SIQUEIRA, 2008; LIRA; CHAVES, 2015). The interest in plantderived drugs, especially from medicinal species, is growing worldwide given that $30 \%$ of the available therapeutic drugs are either directly or indirectly derived from natural products (KOEHN; CARTER, 
2005; LIMA; GOMES, 2014; MENDONÇA et al., 2018).

Brazil is the country with highest biodiversity in the world, with an estimated over 50,000 species of higher plants $(20-22 \%$ of the total worldwide), along with mammals, birds, insects and microorganisms (RODRIGUES, 2016). The use of medicinal plants by the population through living pharmacies and phytotherapy (TORRES, 2015) are essential to meet this demand (ARAÚJO et al., 2013) Brazilian revenue from this sector is approximately US\$ 160 million per year, constituting a promising market whose raw materials are medicinal plants (RODRIGUES, 2016).

The high profitability of herbal drug production contradicts the myth by the synthetic pharmaceutical industry that this market is of little economic importance (CARVALHO et al., 2011). In addition, the implementation of RDC 26/2014, regulating "Traditional Phytotherapy Products", contributed to the sector's development, demanding advances to establish the production chain.

Medicinal plants (native and exotic) and their derivates are used by the Brazilian population and are among the main therapeutic resources for the traditional and complementary/alternative medicine (TM/CAM) used in primary health care, according to a diagnostic by the Ministry of Health (MACEDO, 2016). This enables the appearance of new opportunities for the creation of production cooperatives both in traditional communities and in companies.

According to Marques et al., 2007, establishing policies for medicinal plants and herbal drugs depends on multiple investments in their production chain, namely, by universities and companies (MACEDO, 2016) from the plant to the final product. In this sense, technologies need to be developed that support medicinal plant production from farms to processing units and/or industry. Therefore, there is a socioeconomic demand for investment in medicinal plant production chains from cultivation to processing to advance the national pharmaceutical industry, which depends on the supply of raw material at an industrial scale to develop herbal and natural drugs with safety, efficacy and quality certification; such drugs demand fewer resources and have lower risks than synthetic drug production (CALIXTO et al., 2000; LOPES; NASCIMENTO, 2017; LIMA, 2015; MATOS, 2016).

Drug production is therefore an essential factor of national sovereignty and safety (PADULA, 2017). However, because of socioeconomic and political factors, despite its biodiversity, Brazil still depends on raw material produced by multinationals from developed countries such as USA, China, Israel, Korea and India (CALIXTO, 2000; KOEHN; CARTER, 2005). Given this scenario, for the last 15 years, the Ministry of Health has invested in public policies to promote and consolidate medicinal plant production and strengthen the national pharmaceutical industry. Some of these national policies were the National Policy of Integrative and Complementary Practices - National Policy of Integrative and Complementary Practices - PNPIC (PERFEITO; ANDREOTTI, 2019), the National Policy of Medicinal Plants and Herbal Drugs (National Policy on Medicinal Plants and Herbal Medicines, 2006) and the National Program of Medicinal Plants and Herbal Drugs (National Program for Medicinal Plants and Herbal Medicines - PNPMF).

The public policies mentioned above established important decrees for productive advancement, such as RDC n 60 (2011), approving the Herbal Drugs Form of the Brazilian Pharmacopoeia, which contains 83 herbal drug monographies, and RDC n 13 (2013) of Good Practices for Traditional Herbal Drug Production and the National Drug List (2014).

The National Sanitary Surveillance Agency (ANVISA) regulates the analysis of agrochemical residues in the Brazilian Pharmacopoeia, but residues of undesirable and undeclared substances such as pesticides, radioactive materials, pathogens, mycotoxins, heavy metals and arsenic remain present in plant and herbal drugs (BRASIL, 2011). The PNPMF guidelines establish actions with the aim of promoting technological, economic and social development that require articulation between institutions to stimulate and consolidate the production complex.

The Local Productive Arrangement, which is aimed at strengthening the implementation of this public policy and includes stages from input production (cultivation/management) to industrialized herbal drug production, shows the innovation, economic, technological and social potential of industrialized herbal drugs (TORRES, 2015), and considers family farming one of the main components of this production chain.

In this context, establishing a medicinal plant production chain remains an imminent demand, requiring basic studies from production of inputs to be used in plantations to evaluations of the active components present in the planted species, with the aim of meeting the safety and efficacy 
criteria for medicinal plant and herbal drug production.

\section{Organic production panorama in Brazil}

According to the International Federation of Organic Agriculture Movements (IFOAM), organic production systems are still expanding. Organic production occupies approximately 35 million hectares worldwide, especially in Europe (8.2 million hectares), Latin America (8.1 million hectares - Brazil and Argentina), the USA, Japan and Australia. It is practiced in 150 countries, mostly on family farms (WILLER; KILCHER, 2010).

This expansion is related both to environmental problems and food contamination caused by conventional and industrial agriculture and to the fact that organic-based agriculture is beneficial to biodiversity, environment, fauna and consumers, who have a high demand for products that are chemical free and/or not genetically modified (WILLER; KILCHER, 2010).

According to the 2009 Agricultural Census, organic producers in Brazil represented 1.8\% (or 90,497) of total agricultural farms. The main areas of development are cattle and other animal breeding (41.7\%), temporary plantations $(33.5 \%)$, permanent plantations that include fruit trees and coffee (10.4\%), horticulture/floriculture $(9.9 \%)$ and forestry (3.8\%) (SALVADOR, 2011).

According to the 2006 IBGE Census, approximately 1.7 million hectares are estimated to be under organic management in Brazil (SALVADOR, 2011) with most farms being small, of family origin, and concentrated in the states of Bahia $(15,194)$, Minas Gerais $(12,910)$, Rio Grande do Sul $(8,532)$ and Paraná $(7,527)$.

Although organic production is growing, especially in Brazil, it still faces great difficulties related to public policies, lines of credit, commercialization, investment in specialized technology for input and seed supply, infrastructures, and agro-industries, all of which are factors that affect scale production (WILLER; KILCHER, 2010; ASSIS; MORELLI-AMARAL; PIMENTA, 2015).

In addition, agricultural research has been inefficient in responding to the needs of the organic production system, with the challenge of production expansion being related to research investment, development and technological innovation. Science making and ways of knowledge generation that are not segmented according to the "agrobusiness" development model (conventional agriculture centralized in multinationals) need to be reevaluated.

\section{Agricultural and animal farming residues}

According to a report from the Institute of Applied Economic Research (NOGUEIRA et al., 2015), in 2009 an estimated 291 million tons of residues were generated by agro-industry associated with agriculture, and approximately 1.7 billion tons of waste were generated by animal farming, which are contaminant sources because of their greenhouse gas emissions and nitrogen release into the soil and water (ORRICO JÚNIOR; ORRICO; JÚNIOR, 2009).

Composting is the most effective, alternative and adequate method of solid organic residue treatment for agricultural use (COELHO et al., 2011; LASHERMES; BARRIUSO; HOUOT, 2012). It reuses residues and contributes to environmental conservation, addressing economical and financial questions (NASCIMENTO; FRANCO, 2015) through the generation of new products demanded for agricultural production.

The agricultural and animal farming sector is vast, resulting in high production and availability of residues, both of plant (e.g., coffee straw, sugarcane bagasse, vinasse, saw dust, cakes) and of animal origin (e.g., cattle, horse, pig and poultry manure). In Brazil, the production of these agricultural and animal farming byproducts is distributed per region, which facilitates their reuse for organic compost production.

The main agriculture and animal farming production chains in Brazil are centered on coffee, dairy cattle and sugarcane production. In 2017, the coffee harvest was 45.5 million bags, $79 \%$ of them Arabica coffee; dairy production increased 3\%, with 34.5 billion liters; and sugarcane production increased $2.3 \%$ in 2016/2017, an increase rate that should result in a production of 45.5 million tons in 2026/27 (NASCIMENTO FILHO; FRANCO). This affects the organization of lines of credit, available technologies, and production areas.

\section{Market analyses of organic composts and vermicompost recommended for medicinal plant production}

In Brazil, agribusiness is well developed in terms of goods, products, research and technological services applied to agriculture and animal farming. However, because of the technological packages derived from the Green Revolution, research and technologies are directed at meeting the interests of big companies and multinationals, directly affecting the development of technologies that contribute to 
advances in agroecology, organic production, traditional knowledge, and other sectors of organic production (LAZZARI; SOUZA, 2017).

The internal market is stable in terms of demand for mineral fertilizers, insecticides, fungicides and other products destined for conventional agriculture. However, other agricultural sectors require standardized and certified products regarding their application and recommendation for unconventional agricultural production. Of the production sectors focused on agroecology and its components, the bestestablished production chains are those of big crops, fruit trees and horticulture, and although few, there are some products available to establish such crops in the field.

For medicinal plant production, which is not exclusively focused on biomass yield $\left(\mathrm{kg} / \mathrm{ha}^{1}\right)$ but on the yield of the productive complex, including essential oils and active components with biological and/or pharmaceutical action, there are no commercial products formulated for plant development and production for medicinal purposes.

It should be highlighted that medicinal plant production should not be based on structural or phenological similarity with leaf, fruit and/or root vegetables or with landscaping plants. Medicinal plant production requires research and technology that can promote and establish massive production chains capable of supplying the internal market and strengthening current public policies, such as RENAME, RENISUS, PNPMF and APL.

These public policies are aimed at strengthening the medicinal plant production sector, thus guaranteeing the medicinal plant supply, i.e., the raw material destined for essential drug and dry plant production to be acquired by the users of the Unified Health System (SUS). Although these public policies are currently in force, medicinal plant production remains insufficient to meet the national demand for raw materials.

Basic advancements in medicinal plant production are therefore necessary, namely, regarding inputs (organic composts and vermicompost), plantation and management protocols, and other goods, services and technology. The organic products (organic composts and vermicompost) currently available in the market for agroecological cultivation (organic, biodynamic, ecological and biological), their composition and recommendations for their application to crops are presented in Table 1.

Table 1. List of commercial organic composts and vermicompost available in the Brazilian market.

\begin{tabular}{|c|c|c|}
\hline Product & Composition & Agricultural recommendation \\
\hline \multicolumn{3}{|l|}{ (1) } \\
\hline TeraFértil & Sanitary waste and organic residues & $\begin{array}{l}\text { Citrus trees, eucalypt, sugarcane, flowers, coffee, fruit } \\
\text { trees, trees, flowers and lawns }\end{array}$ \\
\hline SaneFértil & Sanitary waste and organic residues & Eucalypt, sugarcane, ornamental plants, coffee \\
\hline (2) & & \\
\hline $\begin{array}{l}\text { EcoAdubo } \\
\text { Organic } \\
\text { fertilizer }\end{array}$ & Not described & $\begin{array}{l}\text { All types of plants: delicate flowers such as orchids, } \\
\text { roses and violets; ornamental plants, such as ferns and } \\
\text { palm trees, lawns }\end{array}$ \\
\hline $\begin{array}{l}\text { (3) } \\
\text { MAGMAton }\end{array}$ & Not described & $\begin{array}{l}\text { Seedlings, Leaf vegetables, fruit vegetables, tubers, } \\
\text { coffee, cereals, citrus trees, bananas, fruit trees, } \\
\text { gardens, flowers, lawns, pastures and grass fields }\end{array}$ \\
\hline \\
\hline McBiofert & Animal origin and free amino acids & All crops \\
\hline $\begin{array}{l}\text { Folhito MIX } \\
\text { Organic } \\
\text { Fertilizer }\end{array}$ & $\begin{array}{l}\text { Commercial laying hen manure (pure manure), } \\
\text { gypsum (sulfur rich), sewage sludge from cold- } \\
\text { storage rooms and agroindustry (nitrogen rich), } \\
\text { eggshell (calcium rich), ash from wood-burning } \\
\text { boilers (phosphorus rich), unusable feed }\end{array}$ & $\begin{array}{l}\text { Corn, tobacco, soybean, pastures (oat, ryegrass, Tifton } \\
\text { grass, Aries, Brachiaria), wheat, barley, canola, rice, } \\
\text { bananas, onions, native fields, walnut trees, olive } \\
\text { trees, gardens, vegetables, fruit trees }\end{array}$ \\
\hline $\begin{array}{l}\text { Lithothamniu } \\
\text { m Algea }\end{array}$ & Marine algae Lithothamnium & $\begin{array}{l}\text { Cotton, corn, rice and wheat, soybeans, beans and } \\
\text { peanut, sugarcane, coffee and cocoa, garlic, onion, } \\
\text { carrot and yam, potatoes, cassava, leaf and fruit } \\
\text { vegetables, fruit trees, garden plants, ornamental } \\
\text { plants, orchids }\end{array}$ \\
\hline
\end{tabular}


Adubos Ouro Poultry manure

All crops

(5)

Azet

Bagasse, grape stems and seeds, peat, ash from acacia wood, eucalypts and poultry manure and bed.

Alga MC

Marine algae - Ascophyllum nodosum

Citrus trees and fruit trees, melons, watermelons, zucchini, cucumbers, potatoes, onions, artichokes, tomatoes, eggplants, peppers, strawberries, lettuce, spinach, celery, alfalfa, clover, vines

Algasol Marine algae (Ascophyllum nodosum), natural All crops extracts, betaine, oligosaccharides, humic extract

MC Armor

$\mathrm{MC}$

Biocomplex

MC Biogo

Amino acids and biomolecules

Woody plants, vegetables, citrus trees and ornamental plants

Plant extracts and micronized mineral Horticulture phosphorus, amino acids, humic substances and natural plant extracts, yeast protein and rock phosphate.

AATC: $5.00 \%$; Fulvic acid $0.10 \%$

Biole-C

Protein hydrolysate

Biole-R Protein hydrolysate, fulvic acid: $4.80 \%$ Fruit trees, olive trees, strawberries: $4-51 /$ ha; fruits (oligopeptides, extract of algae Ascophyllum and vegetables: 4-5 1/ ha; flowers: 4-51/ ha; seeds nodosum

MC Ecosoil S Granular compost, Humic acids, fulvic acids All crops

10-0-5 $\quad 45 \%$.

MC Ecosoil S Potassium enriched leonardite humic and fulvic Tree species

Humic acids

MC Ecosoil S

Petro $\quad 330$

Ryzeaplus

Algae and RyZeaPlus (last mycorrhizae) and microorganisms

generation

Olive trees: 800-1000; vines: 600-800; cereals: 500700; durum wheat, wheat, lupine beans: 300-400; fruit trees: 800-1000; apricots, tangerines: 900-1100; vegetable crops: $800-1000$; radishes, onions: $600-800$; zucchini, carrots: 600-800; endives, spinach, potatoes: 700-900; tomatoes, 1000-1100; ornamental plants, lawn

MC Fulvic S 95

Fulvic acids: $95 \%$

Not described

MC Humic S 80

Humic organic amendment composed of
potassium humate from American leonardite, treated with potassium hydroxide

MC Humic-

Fulvic 20

Yeast and microorganisms
Alfalfa and forage: $3-10 \mathrm{~kg} / \mathrm{ha}$; rice, cereals and beans: $2-3 \mathrm{~kg} / \mathrm{ha}$; lawns and sport areas: 1-2.5 kg / ha; citrus trees, fruits, bananas and vines: $1-3 \mathrm{~kg} / \mathrm{ha}$; corn, potatoes and beets

Vegetables, fruit, citrus trees: 7-12 1/ ha; Olive trees: 121 / ha; Banana: 50-60

MC Solo Total humic extract 14.37\%; humic acids Vegetables, strawberries, citrus, vines, bananas

Orgânico L 5.62\%; fulvic acids: 8.75\%; ADENINE,

$855 \mathrm{H} 11 \quad$ ZEATIN, BETAINS and MANITOL

(6)

Agrobio
Boric acid, wood ash, castor bean cake, meat Seedlings, leaf and fruit vegetables, perennial crops and bone meal, copper sulphate, cobalt, 
manganese, magnesium, zinc and water, milk, molasses, magnesium thermal phosphate, iodine solution and manure

Biogea Fresh organic matter: fresh manure, remains of Seedlings, fruit and leaf vegetables, perennial crops organic vegetables and fruits, coco-grass, and fruit trees natural phosphate and rock powder

Biofertilizer- Whey, bone meal, ash, molasses and Vegetables, cereals and fruit trees microorganisms

(7)

Folhito Mix pure manure; gypsum - sulfur (S) rich; gardens, rice, bananas, onions and fruit trees exhausted substrate from mushroom production; eggshells - calcium $(\mathrm{Ca})$ and sulfur (S) rich; unusable feed

Folhito Poultry bedding; animal manure; Industrial Compostagem process sweep; sewage sludge; green residues (tree pruning and biomass residues and similar); residues from cafeterias or restaurants; dust from industrial processes (tobacco dust, Not described sawdust and similar); ash from biomass combustion boilers; animal and plant remains in general

(8) Fish hydrolysate (sea fish), sugarcane molasses, Commercial crops and ornamental plants Fishfertil- $\quad$ citric acid and saccharides

Fishfértil K Fish hydrolysate (sea fish), sugarcane molasses, Commercial crops and ornamental plants potassium sulfate, citric acid and saccharides

Fishfértil Fish hydrolysate (sea fish), crustacean Flowers, ornamental plants and lawns

indure hydrolysate (crustacean shells), sugarcane molasses, edible citric acid and saccharides

Fishfértil Fish hydrolysate (sea fish), sugarcane molasses, Commercial crops classic citric acid and saccharides

(9) MZE Rock powder, cereal meal and sugarcane Not described Biorganic molasses

List of Companies accessed: (1) Terra Fértil -organic fertilizer; (2) Plantei - fertilizers - organic; (3). NutriSafra; (4). MfRural; (5) Neudfor; (6) Agrobio; (7) Folhito Mix; (8) Fish fértil; (9) Microbio;

The agricultural and animal farming residue composition of the 33 products listed above is diverse. However, the use of coffee straw and vinasse is not directly mentioned, and most are enriched with some elicitor molecule (fulvic acid, humic acid, free amino acids and algae) in addition to microorganisms that efficiently contribute to promoting plant growth (CALVO; NELSON; KLOEPPER, 2014).

These commercial products are mainly destined for cereals, fruits and vegetables, annual crops and flower production. No recommendations for application to medicinal plants were found. Although many medicinal plants present similar development to some of the listed species, the focus is raw material and not the effect of the commercial product on the elicitation of active components with pharmacological and biological properties.
However, residue recycling is essential to reduce the consumption of natural resources in agriculture, since new products (organic composts and/or vermicompost) are produced from the residues of industrial and agricultural activities, which can be applied to the production of different crops. In addition to allowing for nutrient recycling, these organic composts and vermicompost act as soil conditioner, increasing the levels of organic matter and resulting in improved physical, chemical and biological soil characteristics (WU et al., 2014; MORAES, 2015; LIM; LEE; WU, 2016; SOARES et al., 2017).

However, composting is the most often used and accepted method of organic residue recycling in agriculture because it stabilizes the material, avoiding nutrient immobilization and phytotoxicity (GUIDONI et al., 2013). Organic compost has 
several benefits for agricultural production and for the soil, since in addition to supplying nutrients to plants, it promotes the complexation of toxic elements and micronutrients, improves soil structure, and results in higher microbial activity, soil carbon accumulation, and water infiltration and retention, acting as a soil conditioner (SANTOS et al., 2014).

The reuse of solid residues to produce organic composts and/or vermicompost is therefore a technology with potential for plant growth promotion, since the byproducts of agroindustry (agriculture and animal farming) constitute a health problem (DIAS et al., 2012), contaminating soil, water, air and people when they are not disposed of in a manner that is coherent and responsible toward the environment. In addition, conventional fertilizers that depend on natural resources (mineral fertilizers) are becoming exhausted by the irresponsible exploitation of large agribusiness companies and multinationals.

The need for advances in the production of technologies applied to medicinal plant development and growth that not only promote raw material production but also elicit the secondary metabolism, resulting in higher essential oil yield and active ingredient concentrations, should be highlighted.

\section{FINAL CONSIDERATIONS}

Agricultural production chains are of great importance to the economic movement of small and large producers. However, methods of reusing agricultural and animal farming residues need to be established to avoid contamination of water sources, soil, fauna, flora and population. In addition, countering the agrobusiness production model, organic food production is undergoing constant growth, along with medicinal plant production, with a high demand for technologies, services and products. This sector will only be able to advance through the efforts of research institutions and continuing education, strengthening family farming and the permanence of families in the countryside. The production of specific organic composts and vermicompost for the production of medicinal plants (raw material) rich in active compounds with biological and pharmacological activity is therefore crucial to strengthening the national pharmaceutical industry for both the production of herbal drugs and the consolidation of public policies related to medicinal plants and herbal drugs through the prescription of dry plants by the SUS. It is highlighted that developing technologies and studies for the reuse of residues from sugarcane, beef and dairy cattle and coffee production for the production of commercial products and/or social technology, which can then be reapplied to the production sector, will fulfill the social duty of knowledge of the population and environment, generating jobs, products, sovereignty and food safety through the production of organic food and medicinal plants.

\section{ACKNOWLEDGMENT}

This study was financed in part by the Coordenação de Aperfeiçoamento de Pessoal de Nível Superior - Brasil (CAPES) - Finance Code 001, Conselho Nacional de Desenvolvimento Científico e Tecnológico (CNPq) and Fundação de Amparo à Pesquisa de Minas Gerais (FAPEMIG) for the financial support for carrying out the work.

RESUMO: Embora a demanda por fertilizantes orgânicos na agricultura seja crescente, ela ainda é incipiente em alguns setores produtivos, como a produção de plantas medicinais, que não possui tecnologia específica para seu desenvolvimento. Os resíduos sólidos são altamente contaminantes para fontes de água, solo, populações e biodiversidade, mas podem ser potencialmente utilizados para a produção de compostos orgânicos e vermicomposto, tal produção não só possibilita a reciclagem de nutrientes, mas também atua no condicionamento do solo, aumentando a matéria orgânica do solo e melhorando seu aspecto físico, químico e características biológicas, além do fortalecimento da produção orgânica com ênfase na produção de plantas medicinais. Nesse contexto, foram revisadas as recomendações e aplicações dos fertilizantes orgânicos disponíveis no mercado; além disso, a iminente demanda socioeconômica pela produção de composto orgânico e vermicomposto foi contextualizada a partir dos resíduos da produção de café, cana-de-açúcar e pecuária para aplicação na cadeia produtiva de plantas medicinais. Conclui-se que embora esses setores produzam uma quantidade considerável de resíduos, eles não estão sendo reaproveitados na formulação de compostos orgânicos e vermicomposto, e não foram encontrados fertilizantes orgânicos comerciais recomendados para a produção de plantas medicinais. Sendo assim, a formulação de vermicompostagem e compostagem a partir do 
reaproveitamento de resíduos agropecuários, são potenciais tecnologias sociais, econômicas e ferramentas a serem valorizadas e disseminadas para os agricultores tradicionais e familiares.

PALAVRAS-CHAVE: Agroecologia. Horticultura. Metabolismo secundário. Resíduos sólidos. Sustentabilidade.

\section{REFERENCES}

ALVES, L. F.; PONTES, T. V. C. Research with Chemistry and Pharmacology of Natural Products in Brazil : A Comparison with 70 Selected Countries from 5 Continents. Revista Virtual de Química, v. 9, n. 4, p. 1394 1433, 2017. http://rvq.sbq.org.br . https://doi.org/10.21577/1984-6835.20170082

ARAÚJO, R.F.M.; ROLIM-NETO, P.J.; SOARES-SOBRINHO, J.L.; AMARAL, F.M.M.; NUNES, L.C.C. Phytomedicines: Legislation And Market in Brazil. Revista Brasileira de Farmácia, v. 94, n. 3, p. 331 -341, 2013. https://doi.org/10.1590/S2176-66812013000200001

ASSIS, M. A.; MORELLI-AMARAL, V. F.; PIMENTA, F. P. Research groups and their scientific literature on medicinal plants : an exploratory study in the state of Rio de Janeiro. Journal Fitos, v. 9, n. 1, p. 45-54, 2015. https://doi.org/10.5935/2446-4775.20150005

ASSIS, M.A.; MORELLI-AMARAL, V. F; PIMENTA, F. P. Rearch groups and their scientific literature on medicinal plants : an exploratory study in the state of Rio de Janeiro. Journal Fitos, v. 9, n. 1, p. 1-71, 2015. https://doi.org/10.5935/2446-4775.20150005

BRASIL. Ministry of the Environment. 2011. National Solid Waste Program. Brasilia, 102.

CALIXTO, B, C. J., JUNIOR, J. M. S. The drug Development in Brazil: Challenges. Gazeta Médica da Bahia, v. 78, n. 1.p. 98-106, 2008.

CALIXTO, J.B. et al. Efficacy, safety, quality control, marketing and regulatory guidelines foerbal medicines (phytotherapeutic agents). Brazilian Journal of Medical and Biological Research, v. 33, n. 2, p. 179-189, 2000. http://dx.doi.org/10.1590/S0100-879X2000000200004

CALVO, P.; NELSON, L.; KLOEPPER, J. W. Agricultural uses of plant biostimulants. Plant and Soil, v. 383, p. 3 - 41, 2014. https://doi.org/10.1007/s11104-014-2131-8

CARVALHO, A. C. B.; PERFEITO, J. P. S.; COSTA e SILVA, L. V.; RAMALHO, L. S.; MARQUES, R. F. O.; SILVEIRA, D. Regulation of herbal medicines in Brazil: advances andpepectives. Revista Brasileira de Ciências Farmacêuticas., v. 47, n. 3, p. 467-473, 2011. http://dx.doi.org/10.1590/S1984-82502011000300004

COELHO, C.; CAVANI, L.; HALLE, A.T.; GUYOT, G.; CIAVATTA, C.; RICHARD, C. Rates of production of hydroxyl radical and singlet oxygen from irradiated compost. Chemosphere. v. 85, n. 4, p. 630-636, 2011. https://doi.org/10.1016/j.chemosphere.2011.07.007

COTTA, J.A.O.; CARVALHO, N.L.C.; BRUM, T.S.; REZENDE, M.O.O. Composting versus vermicomposting: comparison of techniques using vegetal waste, cattle manure and sawdust. Engenharia Sanitária e Ambiental, v.20, n.1, p.65-78, 2015. https://doi.org/10.1590/S1413-41522015020000111864

DIAS, D. M., MARTINEZ, C. B., BARROS, R. T. V., AND LIBÂNIO, M. Model to domestic solid waste generation estimative in urban areas based on. Unicamp Scientific and Intellectual Production Repository, 2012. 
ERTHA, V. J. T.; FERREIRA' P. A.; MATOS, A. T.; PEREIRA, O. G. Physical and chemical changes of an argisol by the application of bovine culture water. Brazilian Journal of Agricultural and Environmental Engineering, Campina Grande, v. 14, n. 5, p. 467-477, 2010. https://doi.org/10.1590/S1415$\underline{43662010000500003}$

FLORES, M. P.; GREGORI, M. S.; ARAUJO, L. E. B. Food safety and chemical-dependent agrarian production models. Electronic Journal of the Law Course, v. 8, p. 318-328, 2013. https://doi.org/10.5902/198136948276

GUIDONI, L.L.C.; BITTENCOURT, G.; MARQUES, R.V.; CORRÊA, L.B.; CORRÊA, E.K. Composting at home: implementation and evaluation of the process. Tecno-Lógica, v. 17, n. 1, p. 44-51, 2013.

GURGEL, A. M.; GUEDES, C. A.; GURGEL, I. G. AUGUSTO, L. G. Reflections of the loss of state control of pesticides in Brazil and their regulation by the market. Reciis - Rev Eletron Comun Inf Inov Saúde, v. 11, n. 3, p. 1-16, 2017.

HEINZMANN, B. M.; BARROS, F. M. C. Potential of Brazilian native plants for the development of phytomedications using as an example Lippia alba (MILL.) N . E . BROWN (VERBENACEAE). Saúde, v. 33, n. 1, p. 43-48, 2007. https://doi.org/10.5902/223658346463

IPEA. INSTITUTE OF APPLIED ECONOMIC RESEARCH. Diagnosis of organic residues in the agrosilvipastoril industry and associated agroindustries. Research Report, Brasilia, 2012. 134p.

JIANG, T., MA, X., YANG, J., TANG, Q., YI, Z., CHEN, M., AND LI, G. Effect of different struvite crystallization methods on gaseous emission and the comprehensive comparison during the composting.

Bioresour Technology, v. 217, p. 219-26, 2016. https://doi.org/10.1016/j.biortech.2016.02.046

KOEHN, F.E.; CARTER, G.T. The evolving role of natural products in drug discovery. Nature Reviews Drug Discovery, v. 4, n. 3, p. 206-220, 2005. https://doi.org/10.1038/nrd1657

LASHERMES, G.; BARRIUSO, E.; HOUOT, S. Dissipation pathways of organic pollutants during the composting of organic wastes. Chemosphere, v. 87, n. 2, p. 137-143, 2012.

https://doi.org/10.1016/j.chemosphere.2011.12.004

LAZZARI, F. M.; SOUZA, A. S. Green Revolution: Impacts on Traditional Knowledge $4^{\circ}$ International Congress of Law and Contemporary, 2017. http://www.ufsm.br/congressodireito/anais

LIM, S.L.; LEE, L.H.; WU, T.Y. Sustainability of using composting and vermicomposting technologies for organic solid waste biotransformation: recent overview, greenhouse gases emissions and economic analysis. Journal of Cleaner Production, v. 111, p. 262-278, 2016. https://doi.org/10.1016/j.jclepro.2015.08.083

LIMA, L. O.; GOMES, E. C. Food or medicine? Plant species under Brazilian law. Revista Brasileira de Plantas Medicinais, v. 16, n. 3, p. 771-782, 2014. https://doi.org/10.1590/1983-084x/12_096

LIRA, T. D. M.; CHAVES, M. D. P. S. R. Riverside communities in the Amazônia: sociocultural and political organization. Interações, v. 17, n. 1, p. 66-76, 2016. https://doi.org/10.20435/1518-70122016107

LOPES, K. M. T.; NASCIMENTO, P. R.. Popular Culture and Science in the Phytotherapeutic. Revinter, v. 10, n. 2, p. 122-133, 2017. https://doi.org/10.22280/revintervol10ed2.318

LOPEZ-GONZALEZ, J. A., SUAREZ-ESTRELLA, F., VARGAS-GARCIA, M. C., LOPEZ, M. J., JURADO, M. M., AND MORENO, J. Dynamics of bacterial microbiota during lignocellulosic waste composting: Studies upon its structure, functionality and biodiversity. Bioresour Technology, v. 175, p. 406- 416, 2015. https://doi.org/10.1016/j.biortech.2014.10.123 
MACEDO, J. A. B. Medicinal and phytotherapeutic plants in primary health care: contribution to professionals. Journal Fitos, v. 10, n. 4, p. 32-39, 2017. http://dx.doi.org/10.5935/2446-4775.2016004

MARQUES, L. C.; PETROVICK, P. R. Normatization of the production and commercialization of herbal medicines. In: SIMÕES, C. M. O.; SCHENKEL, E. P.; GOSMANN, G.; MELLO, J. C. P.; MENTZ, L. A.; PETROVICK, P.R.Pharmacognosy: from plant to medicine. 6 ed. Porto Alegre, Florianópolis: UFRGS, UFSC, 327-369, 2007.

MATOS, A. T. Treatment and Agricultural Utilization of Solid Residues. Viçosa, Minas Gerais: Ed. UFV, 2014.

MATOS, P. F.; PESSOA, V. L. S. Modernization Of Agriculture In Brazil And The New Uses Of The Territory. GeoUERJ, v. 2, n. 22, p. 290-322, 2011.

MENDONÇA, M. L.The role of agriculture in international relations and the construction of the concept of agribusiness. International Context, v. 37, n. 2, p. 375-402, 2015. https://doi.org/10.1590/S0102$\underline{85292015000200002}$

MENDONÇA, V. M.; SANTOS, M. J. C.; MOREIRA, F. V.; MANN, R. S.; RIBEIRO, M. J. B. Traditional phytotherapy and integration and complementary practices in the health system of brazil Valéria. Health Themes, v. 18, n. 1, p. 66-97, 2018.

MONTEIRO, E. R.; LACERDA, J. T. D. Promoting the rational use of drugs: a proposal for an evaluation model of municipal management. Health in Debate, v. 40, n. 111, p. 101-116, 2016.

https://doi.org/10.1590/0103-1104201611108

MORAES, J. G. V. Biofertilizers: identification of regulatory barriers and proposals to make this agricultural input viable. 2015. 81 f. Dissertation (Master in Agribusiness) - School of Economics of São Paulo of the Getúlio Vargas Foundation, São Paulo, 2015.

NASCIMENTO FILHO, W. B. D.; FRANCO, C. R. Potential Assessment of Waste Produced Through the Agro-Industrial Processing in Brazil. Virtual Journal of Chemistry, v. 7, n. 8, p. 1968-1987, 2015. https://doi.org/10.5935/1984-6835.20150116

NOGUEIRA, R. E. G.; DAMIN, S.; MAGGI, M. F. LIMA, A. dos S.; JADOSKI, S. J. Disposal of solid waste from livestok activities and risks of environmental pollution in the community of the city of Cascavel - Paraná. Brazilian Journal of Applied Technology in Agrarian Science, v. 8, n. 3, p. 93-101, 2015

https://doi.org/10.5935/PAeT.V8.N3.11

ORRICO JÚNIOR, M.A.P.; ORRICO, A.C.A.; LUCAS JÚNIOR, J. Composting of the solid fraction of swine wastewater. Agricultural Engineering, Jaboticabal. v. 29, n. 3, p. 483-491, 2009.

https://doi.org/10.1590/S0100-69162009000300015

PADULA, R.. Health International Political Economy, strategic autonomy and national security. Revista

Carta Internacional, v. 12, n. 2, p 174 - 196, 2017. https://doi.org/10.21530/ci.v12n2.2017.641

PERFEITO, J. P. S.; ANDREOTTI, P. F. Subject: Analysis of pesticide residues in herbal medicines. 1st edition, Brasília, 2016.

PEREIRA, L. A.; SOUSA, R. A. D. Intensive use of pesticides - the new face of the agrarian issue. OKARA: Geography under discussion, v. 10, n. 1, p. 185-19, 2016.

PIMENTEL, V.; VIEIRA, V. MITIDIERI, T.; FRANÇA, F.; PIERONI, J. P. Brazilian biodiversity as a source of pharmaceutical innovation: a new hope? Revista do BNDES, v. 43, p. 41- 89, 2015. 
RIBEIRO, D. A.; MACÊDO, D. G.; OLIVEIRA, L. G. S.; SARAIVA, M. E. OLIVEIRA, S. F. SOUZA, M. M A. Therapeutic potential and use of medicinal plants in an area of Caatinga in the state of Ceará, nordeste do Brasil. Revista Brasileira de Plantas Mededicinais, v. 16, n. 4, p. 912-930, 2014. https://doi.org/10.1590/1983-084X/13_059

RONDÓ, M.; LOPES, M. Foreign Policy and Democracy: the construction of new paradigms in. Friedrich Ebert Stiftung, 2016.

RODRIGUES, W. Competitiveness and institutional change in the productive chain of medicinal plants in Brazil. Interações, v. 17, n. 2, p. 267-277, 2016. https://doi.org/10.20435/1984042X2016210

SALVADOR, C. A. Analysis of the Agropecuaria Crop 2011/12 Organic Agriculture. Secretariat of Agriculture and Supply, Department of Rural Economy, 2011.

SAMPAIO, R. M. O.; NETO, J. C. G. The paradigm of the intense use of agrochemicals in Brazil under the context of the globalization of agriculture. Journal of Agrarian and Agri-Environmental Law, v. 4, n. 1, p. 111-129, 2018.

SANTOS, A.T.L.; HENRIQUE, N.S.; SHHLINDWEIN, J.A.; FERREIRA, E.; STACHIW, R. Utilization of the organic fraction of urban solid waste for the production of organic compost. Brazilian Journal of Amazonian Sciences, v. 3, n. 1, p. 15-28, 2014.

SAUER, S.; LEITE, S. P. Agricultural Expansion, Prices and Land Appropriation by Foreigners in Brazil. RESR, v. 50, n. 3, p. 503-524, 2012.

SILVA, C.A. Use of organic waste in agriculture. In: SANTOS, G.A. et al. (Ed.): The Basics of Organic Matter: Tropical and Subtropical Ecosystems. Porto Alegre: Metrópole. 2008.

SOARES, J.D.R; REZENDE, R. A. L. S.; REZENDE, R. M.; BOTREL, P. E. CARVALHO, A. M. C.Composting of agricultural residues: A source of humic substances. Scientia Agraria Paranaensis. 2017. v. 16, n. 4, p. 414-421, 2017. http://dx.doi.org/10.18188/1983-1471/sap.v16n4p414-421

SOUSA, A. P.; GOIÁS, B. S. Organic agriculture in Brazil na alternative for agricultural for development. Electronic Journal of Economics of the State University of Goiás, v. 11, n. 1, p. 235 - 247, 2015.

SOUZA-MOREIRA, T. M.; SALGADO, H. R. N.; PIETRO, R. C. L. R. Brazil in the context of plants and derivates quality control. Brazilian Journal of Pharmacognosy, v. 20, n. 3, p. 435-440, 2010. https://doi.org/10.1590/S0102-695X2010000300023

TORRES, K. R. The local productive arrangements (APLs) in the context of the implementation of the Policy and the National Program of Medicinal and Phytotherapeutic Plants. 2015. In: BRAZIL. Ministry of National Integration. Celso Furtado Regional Development Award 2014. Tribute to Armando Dias Mendes. Brasília: Ministério da Integração Nacional. CDD 22.ed. - 615.321

WILLER, H.; KILCHER, L. (2010). The World of Organic Agriculture - Statistics and Emerging Trends. IFOAM

WU, T.Y.; LIM, S.L.; LIM, P.N.; SHAK, K.P.Y. Biotransformation of biodegradable solid wastes into organic fertilizers using composting or/and vermicomposting. Chemical Engineering Transactions, n. 39, p. 15791584, 2014. https://doi.org/10.3303/CET1439264 